\title{
STATI
}

\section{IDENTIFICATION OF A TARGET CONSUMER IN PROCESS OF POSITIONING - THEORETICAL AND PRACTICAL ASPECTS}

Markéta Lhotáková, Anna Klosová*

\section{Introduction}

As the markets are becoming more interdependent and competitive and consumers, on the other hand, are becoming more selective, many companies face the decision on how to effectively address this changing climate. On the one hand, there is a need for product differentiation for the different needs of the different target groups, and on the other hand, standardization of the products is necessary to save costs in the whole process of production and distribution in order to be competitive. Therefore, many international companies try to find internationally valid marketing strategies for their products and brands that will allow them to standardize at least some parts of the marketing mix on more than one market.

A tool was developed for this purpose widely used in internal marketing planning called positioning. For many successful brands and companies, positioning is a key element of their marketing strategies. It identifies the target consumer and the unique benefits that the product (brand) offers to this target consumer and that differentiate it from its competitors. These are the vital decisions in creating a successful and unique marketing strategy.

\section{Definition of Terms - Positioning and Positioning Elements}

There are differences in how positioning and positioning models are described by different authors. But if we take a closer look at these positioning descriptions and definitions, we will see that all of them mention certain core elements of positioning.

* University of Economics, Prague, Faculty of International Relations (anna.klosova@vse.cz, mlhotakova@yahoo.com). 
We can thus identify the major elements of positioning. Positioning is about brands and consumers, about specific consumers and specific needs.

The objective of positioning is to create in consumers' minds a clear position of a brand, which differentiates it from its competitors and represents a clear benefit or value to the consumer. This short statement contains a large amount of information and issues which need solving before any product can reach any certain position. In the first step, we need to answer the following questions:

- Who are the consumers of my product?

- What is their problem (need) that my product satisfies?

- Who are our competitors; how to offer the customers a similar product?

- How can my product/brand satisfy the need of the targeted consumers?

Every author defines positioning differently. For example, Jack Trout, one of the recognized marketing gurus and the first to popularize the idea of positioning products describes positioning in one of his books as "an organized system for finding a window in the mind." . David Aaker, one of the most respected authors on the topics of brand and brand equity, relates positioning to associations. "A well-positioned brand will have a competitively attractive position supported by strong associations. Positioning is closely related to the association and image concepts except that it implies a frame of reference, the reference point usually being a competition" ${ }^{2}$. And so we could continue further.

As a result of our research into the theoretical and practical attitudes toward positioning, we define positioning in the sense of strategic planning tool as follows:

\section{Positioning is how marketers want a brand to be perceived by consumers (group of consumers) in comparison to a competing brand.}

\section{Positioning Elements}

The positioning definition covers four core elements of positioning. The brand is the first of them, of course. But it is not the brand as seen and understood by its owners, but as it is perceived by consumers. Logically, consumers are the second element: who they really are, how to identify the typical consumer for the brand. The third element is the reason why consumers should buy the brand: what benefit, what value this specific brand brings them and how it differentiates from the competitors'. And the four element is the competitors: what differentiates my brand from the competitors', who the competitors actually are and what they offer that we have to compete with.

The core of positioning is a thorough analysis of the consumer, the benefit, the competitors, and the brand itself. As the space of this article is limited, we will concentrate on one area of the positioning element - the target consumer, because the target consumer is central to the positioning strategy. Some authors see segmentation as the core of positioning, for example Kuss and Tomczak understand positioning as

1 Trout, J., Ries, A.: Positioning: Battle for your mind, McGraw-Hill, 2001.

2 Aaker, D., A.: Managing Brand Equity, Capitalizing on the Value of a Brand Name, The Free Press, 1991 , page 110 . 
"achieving a competitive advantage throughout a specific target group", and according to Belch and Belch, it is " the art and science of fitting the product or service to one or more segments of the broad market in such a way to set it meaningfully apart from competition". 4

In this article, we will outline the most important theoretical bases for identification of the target consumer, and the application of this theory to a real case will be shown in the second part. It will outline an example of the process of target group identification for the purpose of positioning statement and strategy development. It will indicate how the segmentation and targeting process may be implemented in reality.

\section{Target Consumer and Positioning Concept}

A key positioning objective is to develop such a brand perception that will resonate with consumers' expectations because of compelling value proposition or because of another benefit that differentiates the brand in the consumers' mind compared to the competitors'. The core of this objective is the consumer and his or her perception of a brand. To be able to create a positioning strategy leading to the desired brand perception, we need to understand the consumer. Consumers are different. They are of different age, social class, education, nationality etc., they have different values, preferences and motivations, and therefore they are buyers and users of different products and services. The target consumer, as one of the key positioning elements, is not just anybody from within the masses. The target consumer in the positioning concept is possibly a homogenous group of consumers interested in similar benefits accommodating a certain need or wish. To be able to develop a positioning strategy for a brand, it is vital to identify and deeply understand the target consumer.

At first we need to identify a potential target audience - consumers with similar needs and expectations. Then we also need to learn about consumers' motivation to purchase a certain product and a certain brand. It is necessary to understand the purchase decision-making process and the motivations behind it: why the consumer buys a certain product, when and why s/he is using it, what kind of benefit $\mathrm{s} / \mathrm{he}$ has or expects to have from the product and the brand.

Segmentation is vital to positioning. It is a key tool to identify the target consumer as well as an important cue for benefit identification. In this chapter, we will refer to segmentation as a tool for identification of a target audience and its profile identification.

\subsection{Segmentation}

Segmentation is an extremely important element of a positioning strategy. Market segmentation is dividing a market into distinct groups that have common needs and will

3 Kuss, A., Tomczak T.: Marketingplannung, Wiesbaden, Gabler 1998.

4 Belch, G. E., Belch M.A.: Advertising and Promotion: an integrated marketing communications, Irwin 1995. 
respond similarly to a marketing action ${ }^{5}$. From the positioning point of view, it is very important to look into motivations for the purchase; that means, what kind of benefit or service the consumer expects from the product. The way and occasions of its usage usually help to understand them. Different types of media and promotions may also reach different segments, and that is very important for advertising and communication. There are many product-relevant characteristics according to which segmentation splits consumers into groups: age, sex, income, lifestyle (where and how they live), loyalty to a certain product or service, intensity of usage (heavy or light users), and behavioral patterns. There are many different ways to divide the total market into groups of consumers with similar expectations and needs. The marketers' imagination is the only limit to segmentation.

Segmentation is only possible if based on a relatively large amount of information about consumers and their effective and professional evaluation. The smaller and more compact segments we try to find, the more information we need. What is more, this type of information is not always easy and cheap to find.

Some market research companies, media agencies and multinational corporations have developed their own, new and creative ways of segmentation to overcome the obstacle of traditional market research used in the same way by competitors. One of the effective ways to discover new segments is studying consumer behavior. Knowledge of the hierarchy within the decision-making, purchase and usage process may help to discover important aspects of segmentation.

Segmentation is a creative process limited only by marketers' imagination and companies' resources. Segmentation is not a static process. It needs to be periodically repeated, as markets are dynamic and consumers' behavior changes naturally along with changing lifestyles, life cycle stages and responses to competitive activity, social milieu development, etc.

\subsection{Ways of Segmentation}

As already mentioned, there are different types of information according to which the markets can be segmented. There are unlimited amounts and types of information and variables according to which marketers segment markets. In addition, new ones are emerging all the time as a result of research for new unoccupied markets. But in marketing theory, the majority of authors recognize five groups of segmentation variables. Some of these variables (demographic, geographic) are of a more descriptive character, while others, like psychographic and behavioral patters, are oriented on consumer preferences, feelings and perceptions. Those are important not just for target audience identification and description, but also for benefit identification. 1995, p. 133. 


\section{Geographic Segmentation}

In geographic segmentation, markets are divided into different geographic units. These units may include cities, regions, countries, or continents. Sometimes consumers may have different buying habits, needs and expectations depending on where they live. This type of segmentation is more likely to be used at the execution level rather than the strategic level of planning. Geographic segmentation is more often used for planning of marketing mixes. At the level of strategic planning, geographic segmentation is more likely to be used for description and identification of the target segment.

\section{Demographic Segmentation}

In demographic segmentation, markets are divided into segments on the basis of demographic criteria like age, sex, family size, education, income, and social class. Consumers with similar demographic variables tend to have similar expectations, preferences and usage habits. The demographic variables can be compared to other segmentation variables, relatively easy to obtain and evaluate. However, many consumer attitudes and behaviors are not demographically driven and, in many cases, are not even demographically related. Therefore, the marketer shall employ an additional basis for segmentation. Similarly to geographic segmentation, demographic segmentation is often used as a tool for identification and description of segments.

\section{Psychographic Segmentation}

Dividing the market on the basis of social class, personality and/or lifestyle is referred to as psychographic segmentation. While it may be up to discussion whether personality is a useful and relevant criterion for segmentation, lifestyle factors belong to the most effective criteria of segmentation.

Determination of lifestyles is usually based on an analysis of the consumers' activities, interests and opinions. These lifestyles are then correlated with the consumers' product, brand or media usage. Lifestyle segmentation is used successfully in many different product categories from food and clothing to the car industry.

Several standardized psychographic segmentations have been developed by different marketing research agencies. The most commonly used ones include the Value and Lifestyles (VALS) program developed by Stanford Research Institute. The VALS segmentation system sorts consumers into an eight-part typology based on their motivations and demographic characteristics. The typology in VALS is suited to the US market. It has been proven that using this typology blindly on other markets might be mislea$\operatorname{ding}^{6}$. Therefore, a number of lifestyle studies have been conducted for use in international marketing. Most of them describe typology, and focus on changes in people's lifestyles for use in new product development, new product introduction and brand positioning. They do not describe cultural dimensions.

6 Mooji, M. K. de.: Global marketing and Advertising, Understanding Cultural Paradoxes Saga Publications, Inc., 1998, p. 121. 


\section{Behavioral Patterns}

Behaviorist segmentation divides consumers into groups according to actual behavioral patterns while using a particular product or service, like regularity of usage, loyalty, occasion of usage, benefit enjoyed from purchase and usage. Several commonly used variables of behavioral patterns can be applied.

\section{Regularity of Usage}

This way of segmentation differentiates between heavy users, who use the specific product very often, light users, who use the product less often or intensively, and non-users, who do not use the product at all. Regularity of usage may be used to indicate different target groups (producer may target heavy users or light users), or it can merely be a cue for further research and segmentation of target consumer behavior (for example research of motivations and values - how to motivate light users to become heavy users).

\section{Loyalty}

Loyalty segmentation is based on the strength of the ties that consumers have to certain brands. Loyalty has five levels each of which represents the tie between the consumer and a specific brand. The scale goes from the most loyal committed consumers, who continuously stick to one brand, to switchers, who most likely purchase a different brand each time, mostly depending on the price or other promotional advantages. Loyalty may be connected to regularity of usage of a specific brand. One of the ways to measure loyalty is to measure repetitive purchase and usage of the brand ${ }^{7}$. To understand consumer behavior, it is useful to study reasons and motivations for the certain levels of consumer loyalty.

\section{Benefit Segmentation}

Benefit segmentation groups consumers on the basis of attributes that satisfy specific consumer needs. By purchasing products, consumers generally try to satisfy needs, wishes or aspirations. That means that consumers actually look for specific benefits that products may provide to satisfy these needs rather that looking for products. It is important to know what kind of benefits the product may offer to be able to address the consumer with the right motivation. As these benefits may be very different for different segments, benefit segmentation has become one of the most important parts of the segmentation process. The Unique Selling Proposition (USP) is one of the marketing concepts based on benefit satisfaction. This concept was pioneered already in the 1950s by Rosser Reeves and Ted Bates advertising agency and was focused on differentiation in advertising. The idea behind the USP concept is that advertising should give

7 Although some Authors (Keller, L. K.: Strategic Brand Management, Prentice hall, 1998) consider this as incorrect and misleading measurement of loyalty as consumers may have other motivations for repetitive purchase than loyalty. 
consumers a compelling reason for product purchase based on a distinctive, unique product benefit. $^{8}$

Consumer benefit is a key to positioning. With respect to positioning strategy development, the benefit is also one of the key elements for segmentation of the market and identification of a target audience. The target audience, as one of the positioning strategy elements, shall be a group of consumers with similar expectations in respect to the product benefit. As the product benefit is an important marketing category, there has been a lot of research into it.

\section{Purchase and Usage Occasion}

The occasions on which certain products are purchased and used may differ quite a lot in different consumer groups. Insight into consumer behavior around purchase and consumption may help to identify new usage opportunities and key decision-making factors the in purchase process, but also to investigate consumer benefits. There are many different ways and objectives of research into consumer behavior around purchase and usage. Most of these methods try to identify values and motivations behind consumer behavior. These studies are usually closely connected to consumer benefit identification.

Segmentation is not an easy task. Usually several variables from almost all groups are used. Using multiple variables and criteria helps to concentrate on a more specific, tighter market segment. A tighter segment means a more relevant offer to the customer, higher customer satisfaction and less waste of resources. From the point of view of positioning, it is important to concentrate on such variables that identify consumers with shared expectations and preferences and lifestyles, based on which a common benefit may be created. Geo-demographic data are usually used as a tool for identification and description of such a segment.

\subsection{Targeting}

Segmentation is the first step in identifying a target consumer. After determining which segments are valid and analyzing the profile of the target consumers in these segments, it needs to be evaluated, whether the segment is attractive for the particular product and brand. Careful analysis should reveal if and which segment suits the brand and the producer and which segment should be selected and addressed. This process involves two steps, determining the potential suitable and profitable segments and determining how many of these segments to enter.

The first step is to determine which segments are worth addressing with an offer. That means, on which segment or segments the brand shall be targeted. Such segments should fulfill several criteria in order to be suitable for entry or continued offering.

- The customer base in the segment shall have relatively strong and homogeneous shared preferences or expectations as concerns the product and product benefits. On top of that, consumers in such a segment must be easy to identify and to reach.

8 Keller, L. K.: Strategic Brand Management, Prentice hall, 1998, p. 116. 
This target audience shall also be similarly reachable and responsive to marketing programs.

- It is necessary to consider the size of the market segment; i.e., whether the segment is large enough to be worth the effort and the investment. If the target segment is too small, it is likely to be unprofitable; if the segment is too big, it can be expected to attract a lot of competition and it may become difficult to compete. Market segment size should also be relevant to the company size.

- It needs to be considered if the market segment can be serviced at an acceptable level of costs (product development, production, distribution, communication). Can a price be achieved that generates reasonable profit? Again, if the segment is very profitable, it is likely to attract a lot of competitors.

- Another important criterion is the stage of the life cycle in which the market segment currently is.

- It is important to identify all competitors in the segment; i.e. who the competitors to my product and brand are in a particular segment, the direct and indirect competitors, the local and international competitors, the current and potential future competitors.

The second step of targeting is to determine how many potentially suitable segments the company shall enter and with what strategy. There are generally three different strategies of segmentation and targeting:

- Undifferentiated strategy - a mass marketing approach that ignores differences among the segments. The whole market is considered to be undifferentiated and the product or brand is targeted to anybody.

- Differentiated strategy - the same product or brand are offered in two or more segments but with a differentiated marketing strategy in each of them.

- Concentrated strategy - focuses on one market segment with one product or brand and with a completely unique marketing mix.

Generally speaking, a positioning strategy is compatible with a differentiated or concentrated strategy. From the point of view of positioning, a concentrated strategy is the most suitable. A concentrated strategy presumes uniqueness of the market segment. It is easier to find a common and, on top of that, unique benefit for a target group. The more homogenous this group is, the easier it is to find one. That is exactly the aim of positioning. On the other hand, this strategy limits the size of the market for the brand to just this consumer group.

A differentiated strategy already requires compromising on the elements of the positioning strategy as it addresses more than one market segment. The most commonly used is the compromise on the benefit or brand. The producer may offer the same product under the same brand with different benefits to two different market segments. More commonly, producers serve different market segments with similar products under different brands with different benefit offers. This attitude limits potential confusion about the brand benefit among the target segments in exchange for a higher cost. This 
attitude requires careful brand management to clearly target and differentiate the brand and to minimize cannibalization.

An undifferentiated strategy, in general, presumes that all consumers are similar and would buy the same product. In this case, it really does not make sense to try to identify differentiating points for the brand. In reality there are very few, if any, producers who pursue this strategy nowadays. Even so-called global products, or rather global brands are targeted at certain segments, usually the largest ones, and adopt at least certain elements of the marketing strategy at the level of a marketing mix to a locally specific target audience.

\subsection{International Aspect of Segmentation}

When segmenting markets, the international and global aspects should not be forgotten. Some markets and market segments are international; some are even global. That means that the same or very similar consumer groups can be found in different countries around the world. These markets present new opportunities, but also new competitions.

With respect to strategic marketing planning and positioning, it is important to mention the international and global dimensions of segmentation. It has become common that multinational corporations develop the majority of product and brand strategies for the international environment. Especially psychographic and behavioral pattern variables may show that there are similar market segments in geographically and demographically very different markets. With growing competitive pressures, it is becoming more and more important to research for such market segments in order to be able to use the economy of scale at both the production and marketing levels. This does not mean that geographic segmentation in the sense of local (national, regional) specialties is not important any more. For many product classes, a strategy of mixed international brands in the sense of brand positioning with local adaptations to the marketing mixes is currently proving very effective. At which level the marketing mix can be used internationally, especially in communication and advertising, needs to be carefully evaluated based on segmentation analysis. An example of international segmentation for the purpose of positioning strategy development is shown in the Bosch case study below.

\subsection{Segmentation and Positioning}

The whole concept of marketing is to attract the consumer through satisfaction. With growing competition, new and more precise strategies are being developed to address consumers with specific offers. Positioning is based on the brand image creation in the consumers' eyes. But who are these consumers? What do they expect from different products and brands? How do these products and brands satisfy them?

Therefore, segmentation is one of the vital elements of a positioning strategy. Its aim is to identify a target audience and find out its common characteristics. Through deep analysis it tries to understand the psychology of consumers' behavior that is in any way connected to product purchase or usage.

As a result of this step of positioning strategy development, a clear profile of the target consumer shall be drawn. It shall consist of descriptive characteristics, according 
to which it can be identified (demographic, geographic, psychographic characteristics) and from behavioral and psychographic characteristics, which are important for the identification of the brand benefit. The more information about the consumer the segmentation brings, the more likely the positioning strategy is to succeed.

\section{Case Study - Bosch Home Appliances}

\subsection{Background on Bosch Home Appliances}

Bosch is a traditional German brand of technical products ranging from home appliances through automobile parts to industrial electronic systems. Within the home appliance market it is one of the leading brands globally and the market leader in Europe ${ }^{9}$. Despite this relative strength, its absolute market position is not particularly strong. Its value market share of $9.3 \%$ Europe-wide indicates that the market is quite fragmented and there is still a large potential for market share and sales growth. But significant changes on long-established markets are only possible with solid plans and sound strategies, based on brand equity building. This was one of the reasons why the mother company Robert Bosch $\mathrm{GmbH}$ carried out a brand image and brand equity study in June 2001. The result showed significant weaknesses in the brand image and the related deficit in brand equity.

Based on these facts, the home appliances division decided to develop a new strategic brand plan aiming at improving the brand image across Western Europe and, if successful, in other European as well as non-European countries. One of the major pillars of such strategy is a clear positioning of the brand relevant to the market and target consumers.

The formulation of positioning, or positioning statement for Bosch home appliances required an in-depth study of the market situation, consumer trends, needs and perceptions as well as of internal company resources. Part of this process was also identification of a target audience, which will be in more detail elaborated in the following text.

\subsection{Trends in Home Appliance Purchasing}

The home appliances market is a relatively low-involvement market with a long purchase cycle. In Western Europe, a new home appliance is bought every eight years on average, and the purchase decision is made within a few days or even hours before the purchase. This can be explained by the facts that the majority of the purchases are replacements of older appliances and that an appliance is more or less considered to be a functional rather than emotional or self-expressive element of the household.

But there are also certain trends in the home appliances market which influence purchase decision and which need to be addressed. Within these general trends, different lifestyles can be identified based on different values across all European countries. Accordingly, there are different attitudes towards family life, roles of the 
family members in the household, and the related importance of kitchen and home appliances as well as the value of leisure time. To identify various lifestyles and hence target groups with their values and attitudes, all sorts of lifestyle studies are conducted. Most describe typologies and focus on changes in people's lifestyles for the purpose of new product development, new product launches and positioning of brands.

To identify the potential target groups in European countries and to analyze the potential for common target grouping across Europe or at least at some markets as part of the development of the European positioning strategy, BSH has commissioned a specialized market research study focused on identification of major consumer segments across Europe. The study has not only identified the segments and their sizes, but also offered an in-depth description of socio-demographic attributes. The following section will show some major steps of the elaboration of the study and its application in positioning strategy development.

\subsection{Market Segmentation}

A traditional brand, Bosch already has an established group of customers, and therefore there are certain limits to the change in the selection of the target group. Bosch is currently positioned as a high-quality product within the lower premium price segment. Consumers in the current target group have a mid to higher income level, A and B social classes. This is more or less valid for all European markets, with a bit lower premium position in Germany. But such targeting is too general for the purposes of clear positioning. There needs to be more insight into consumers' needs, usage and expected benefits. Such information, however, cannot be obtained from simple geodemographic segmentation.

Another important aspect of the segmentation process in Bosch is the intention to develop an internationally valid positioning for at least some European markets. Therefore, it has been attempted to find such a segment or segments which appear in as many as possible European countries and which at the same time can be addressed with benefits not totally distant from the Bosch brand.

To identify such segments, BSH has conducted a segmentation study focused on different dimensions. The main segmentation perspective used was behavior, especially usage and benefit, but the study goes deeper in analyzing the identified target groups and describes social demographics, psycho-demographics, and the already mentioned behavior in connection to the home appliances.

Fifteen different segments have been identified in Europe based on the main criteria: usage and benefit. Some of them have quite a national character, while others were identified across more, or even all, European countries. All of these segments, no matter in which country they exist, can be sorted into four different groups according to the main source of the benefit. Table 1 shows all the identified segments with a short characteristic in connection with home appliances. They are divided into groups, depending on the source of the main consumer benefit (whether it is the product itself, the usage of the product, or the combination of the product itself and its usage, or target groups with little interest in the products and their usage-low-involvement segments). 
Table 1

Europeans Segment Description

\begin{tabular}{|c|c|c|c|}
\hline Segment & Segment profile & $\begin{array}{c}\text { Consumer need } \\
\text { expression }\end{array}$ & $\begin{array}{c}\text { Source of consumer } \\
\text { benefit }\end{array}$ \\
\hline Expressor & $\begin{array}{l}\text { The things I own say } \\
\text { something about who } \\
\text { I am. }\end{array}$ & $\begin{array}{l}\text { Everything with } \\
\text { innovation and design }\end{array}$ & Product \\
\hline $\begin{array}{l}\text { (Young) Design } \\
\text { Connoisseur }\end{array}$ & $\begin{array}{l}\text { Design is important in } \\
\text { all areas including } \\
\text { household appliances. }\end{array}$ & $\begin{array}{l}\text { Modern quality } \\
\text { products for the eye }\end{array}$ & \\
\hline Status Driven & $\begin{array}{l}\text { I can afford to chose } \\
\text { the best. }\end{array}$ & $\begin{array}{l}\text { The most expensive is } \\
\text { just enough }\end{array}$ & \\
\hline Home Hedonist & $\begin{array}{l}\text { I enjoy spending time } \\
\text { at home. My } \\
\text { surroundings are } \\
\text { pleasurable and make } \\
\text { me feel happy. }\end{array}$ & $\begin{array}{l}\text { Mix of design, } \\
\text { technology and } \\
\text { innovation to express } \\
\text { personality and } \\
\text { harmony }\end{array}$ & \\
\hline Sociable & $\begin{array}{l}\text { These products are a } \\
\text { part of my way of life. }\end{array}$ & $\begin{array}{l}\text { Everything for the } \\
\text { family }\end{array}$ & Usage \\
\hline Time Saver & $\begin{array}{l}\text { These products give } \\
\text { me time to do other } \\
\text { things. }\end{array}$ & $\begin{array}{l}\text { Everything that makes } \\
\text { life easier }\end{array}$ & \\
\hline Simplicity Seeker & $\begin{array}{l}\text { I just need a simple, } \\
\text { basic product. }\end{array}$ & Simple handling & \\
\hline Brand Believer & $\begin{array}{l}\text { I prefer to trust a } \\
\text { national brand. }\end{array}$ & It must be a brand & Usage and product \\
\hline Home Enthusiast & $\begin{array}{l}\text { I enjoy investing in my } \\
\text { home. }\end{array}$ & $\begin{array}{l}\text { Quality products for } \\
\text { comfort }\end{array}$ & \\
\hline Household Manager & $\begin{array}{l}\text { I am proud of my } \\
\text { kitchen equipment. }\end{array}$ & $\begin{array}{l}\text { Professionalism and } \\
\text { quality }\end{array}$ & \\
\hline Shrewd Enthusiast & $\begin{array}{l}\text { I won't pay more than I } \\
\text { have to for a quality } \\
\text { product. }\end{array}$ & $\begin{array}{l}\text { Quality and innovation } \\
\text { at a favorable price }\end{array}$ & \\
\hline Expert Investor & $\begin{array}{l}\text { I know how to make } \\
\text { the right choice for a } \\
\text { long term investment. } \\
\text { I enjoy advising my } \\
\text { friends/family. }\end{array}$ & $\begin{array}{l}\text { The newest products } \\
\text { with design and } \\
\text { convenience }\end{array}$ & \\
\hline Reluctant Adopter & $\begin{array}{l}\text { Why can't these } \\
\text { products be simpler? }\end{array}$ & $\begin{array}{l}\text { Few uncomplicated } \\
\text { functions }\end{array}$ & Low involvement \\
\hline Utilitarian & $\begin{array}{l}\text { It's only as good as it } \\
\text { works! }\end{array}$ & The essential & \\
\hline $\begin{array}{l}\text { Economically } \\
\text { Constrained }\end{array}$ & & $\begin{array}{l}\text { Even basic equipment } \\
\text { is a luxury }\end{array}$ & \\
\hline
\end{tabular}

Source: BSH Internal materials, Segmentation study.

These segments can be divided into four groups (as shown in Table 2). Each of these groups represents segments that are somewhat similar in terms of the main benefit expected from the home appliance. There is a group of segments in which the consumers value the product itself, its design, technology and certain personality as the most im- 
portant. In another group the usage of the appliance, the product quality in connection with its functions and ways of handling are the most important benefits. Both of these groups have their expectations from the appliance, which do not go beyond the product or its usage. They appreciate appliances that satisfy their needs, but they do not consider them as important elements of their lives. The third group of segments contains target groups with a little more involvement. They see the benefit in a mixture of product and usage features. These consumers care about the personality of the product, its design as well as about the usage features and quality. Segments within this group mostly differ in the size of the investment they are willing to make in a home appliance. In a complete contrast to them stand the target groups in the fourth group, which have very little interest in the home appliances. Consumers in all these three segments see home appliances as something that may help them, but they intend to give it as little attention and investment as possible. Table 2 shows brief characteristics of these four groups.

Table 2

Characteristics of four major groups of consumer segments

\begin{tabular}{|l|l|}
\hline Group of consumer segments & Characteristics of the group \\
\hline \multirow{4}{*}{ Product and usage } & - is interested in home appliances \\
& - purchase is considered investment for which corresponding \\
& price is paid, for the majority the price is not decisive \\
& - likes to be informed about novelties and innovations \\
& - puts emphasis on innovation \\
- prefers branded products
\end{tabular}

Source: BSH Internal materials, Segmentation study.

Another important characteristic of the segments is their geographic presence. Some of them have been identified only on some European markets, but three of them are present on all the markets. Table 3 shows the presence of the individual segments on national markets and their sizes in percent of the households. They are grouped by the main benefit expected by the consumers. 
Table 3

Presence of Segments on European Markets and their Sizes in Percent of Households

\begin{tabular}{|c|c|c|c|c|c|c|c|c|}
\hline Segment & D & UK & $E$ & $\mathbf{F}$ & I & DK & PL & GR \\
\hline & \multicolumn{8}{|c|}{ Product } \\
\hline Expressor & 16 & 22 & 15 & 17 & 8 & 6 & 13 & 3 \\
\hline Design Connoisseur & & 5.5 & & & & & & 18 \\
\hline $\begin{array}{l}\text { Young Design } \\
\text { Connoisseur }\end{array}$ & & & 13 & & 12 & & & \\
\hline \multirow[t]{2}{*}{ Home Hedonist } & & & & & & & & 22 \\
\hline & \multicolumn{8}{|c|}{ Usage } \\
\hline Sociable & 10 & 6.5 & 14 & 17 & 35 & 18 & 8 & 5 \\
\hline Simplicity Seeker & & & & 24 & 25 & & 8 & 19 \\
\hline \multirow[t]{2}{*}{ Time Saver } & 10 & 5 & 8 & & & 22 & 10 & \\
\hline & \multicolumn{8}{|c|}{ Product and usage } \\
\hline Brand Believer & & & & 22 & & & & 11 \\
\hline Home Enthusiast & 19 & & & & & 34 & 19 & \\
\hline Shrewd Enthusiast & & 32 & & & & & & \\
\hline \multirow[t]{2}{*}{ Expert Investor } & & & & & & & & 12 \\
\hline & \multicolumn{8}{|c|}{ Low involvement } \\
\hline Utilitarian & 28 & 10 & 25 & 24 & 13 & 20 & 36 & 10 \\
\hline \multirow[t]{2}{*}{ Reluctant Adopter } & 15 & 14 & 18 & & & & & \\
\hline & \multicolumn{8}{|c|}{ No segment } \\
\hline $\begin{array}{l}\text { Not belonging to any } \\
\text { segment }\end{array}$ & 3 & 5 & 7 & 9 & 11 & 3 & 4 & \\
\hline
\end{tabular}

Source: BSH Internal materials, Segmentation study.

The objective of the consumer analyses conducted by BSH for the purpose of development of Bosch positioning for Western Europe was the possible identification of target groups that possess similar characteristics and similar attitudes toward the purchase of durable home appliances. A specialized segmentation study that was conducted across all Western European markets identified 13 consumer segments, which could be clearly identified and closely described in relation to their purchase and usage attitudes to home appliances.

The common preferences and benefits that each of these segments expects from a home appliance can be identified. As the study was conducted across all Western European countries, there is also a clear result as to which segment is national (expert investors in Greece), which is regional, and which is European (expressors, sociables, utilitarians).

Which of these groups is/are suitable as target consumers for the Bosch home appliances strategy and positioning has to be decided in the context of other positioning elements in the process of positioning strategy development. 


\subsubsection{Targeting - Selection of a Target Group for Bosch Home Appliances}

To identify a suitable target group for Bosch home appliances, it is necessary to connect the current brand characteristics and strengths with the characteristics of these segments and potential brand benefits. Are there any target groups whose benefit would also be a core value of the Bosch brand and could help to differentiate Bosch? Is this target group large enough to be profitable if addressed? Does this target group have a future potential? What about the other BSH brands, are they targeted to another segment to avoid cannibalization? Is this target group internationally present?

All these questions need to be addressed when evaluating the segments and choosing the right target group for Bosch. The first step is to compare the core values of the Bosch umbrella brand with the current perceived values of Bosch and with the values required by the individual segments and identify those segments that have some common characteristics.

Table 4 summarizes the core values of the Bosch umbrella brand and the perceived values of Bosch home appliances. Bosch home appliances do stand for the same core brand values as the umbrella brand, but the umbrella brand represents a much wider set of values on top of high quality and innovation. When looking for the target group, the core brand values, high technical and technological quality as well as some of the umbrella values (experience and competence, durability, functionality) will be seen by the target group as important benefits.

\section{Table 4}

Comparison of Core Values of Bosch Home Appliances with those of the Umbrella Brand

\begin{tabular}{|l|l|l|}
\hline Product category & \multicolumn{1}{|c|}{ Values per category } & \multicolumn{1}{c|}{ Common values } \\
\hline $\begin{array}{l}\text { Bosch umbrella brand core } \\
\text { values seen as a company } \\
\text { heritage are }\end{array}$ & $\begin{array}{l}\text { - high technical and } \\
\text { technological quality, } \\
\text { - experience and competence, } \\
\text { - functionality, durability, } \\
\text { uncompromising reliability, } \\
\text { - semi-professional products }\end{array}$ & $\begin{array}{l}\text { - high technical and } \\
\text { technological quality } \\
\text { (innovative) }\end{array}$ \\
\hline $\begin{array}{l}\text { Bosch home appliances } \\
\text { perceived image/values }\end{array}$ & $\begin{array}{l}\text { high quality, technology and } \\
\text { innovation }\end{array}$ & $\begin{array}{l}\text { - high technical and } \\
\text { technological quality } \\
\text { (innovative) }\end{array}$ \\
\hline
\end{tabular}

Source: BSH Internal materials.

Also the fact that company has to manage more brands needs to be respected while segmenting the market and looking for the suitable target group. Before selecting the target group, it is important to consider other BSH brands' perceived values and positioning. It is vital that the positioning and therefore also target groups for each brand differ, otherwise the brands would cannibalize their business among themselves rather than 
from competitors. Table 5 shows the main selling propositions of the second internationally marketed brand Siemens and two specialty brands Gaggenau and Neff (also internationally marketed), which need to be considered as potential direct competitors.

If we take a closer look at these brands and their core values/selling propositions, we can see that there are two brands, Gaggenau and Neff, offering only built-in appliances, which is already a differentiation from Bosch. Furthermore, Gaggenau clearly has a different selling proposition and positioning from Bosch, targeting the most premium design oriented consumers who expect a very individual service. Neff, although it shares with Bosch the high quality value, is as a built-in brand more oriented on design as a second major value. The differentiation between Siemens and Bosch is the most important. As shown in the Table below, Siemens tries to position itself as an innovative, modern, hi-tech, design appliance for contemporary individuals. With this intended positioning (which is not entirely in line with the perception, as we have already seen), Siemens is quite clearly addressing the target audience segments with the major interest in the product (Expressors, Design connoisseur, Home hedonists). These are the segments Bosch shall not try to address with its offer.

\section{Table 5}

Selling Proposition of Major BSHG Brands

\begin{tabular}{|l|l|l|}
\hline Brand & \multicolumn{1}{|c|}{ Core values - selling proposition } & \multicolumn{1}{c|}{ Target segment specialization } \\
\hline Bosch & $\begin{array}{l}\text { Quality } \\
\text { Technology and innovation }\end{array}$ & "Aim of the Analysis" \\
\hline \multirow{3}{*}{ Siemens } & $\begin{array}{l}\text { Innovation } \\
\text { Design } \\
\text { Hi-tech } \\
\text { Individuality }\end{array}$ & $\begin{array}{l}\text { Product oriented segments - } \\
\text { expressors, (young) design } \\
\text { connoisseurs, }\end{array}$ \\
\hline \multirow{3}{*}{ Gaggenau } & $\begin{array}{l}\text { Authentic designer brand } \\
\text { Individuality } \\
\text { Exclusivity } \\
\text { Specialized in built-in appliances }\end{array}$ & $\begin{array}{l}\text { Niche segments - status driven, design } \\
\text { connoisseurs }\end{array}$ \\
& $\begin{array}{l}\text { Specialized in built-in appliances } \\
\text { High quality } \\
\text { Design }\end{array}$ & $\begin{array}{l}\text { Niche segments - Home hedonists, } \\
\text { Home Enthusiasts, Expert Investors }\end{array}$ \\
\hline
\end{tabular}

When considering all these above mentioned aspects, we can conclude that Bosch should address any of the target groups stressing the importance of high quality and functionality, which means the segment groups oriented on usage or product and usage. Consumers in these segments consider high quality in a functional sense as well as other characteristics close and important to Bosch. Together with this aspect, we shall also consider the size of the market and its international presence when selecting a suitable target group. Table 3 shows that the segments where consumers consider the product as well as usage important are quite special and only exist in a few countries. They are not large enough to be worth considering for an internationally marketed brand like Bosch. 
On the other hand, the segments where consumers consider usage of the product to be the most important include the segment of sociables, which is present all across Europe and in some countries represents quite a significant share of the market. Sociables therefore seem to be a suitable potential primary target for Bosch home appliances.

\section{Major Characteristics of Sociables ${ }^{10}$ as Resulted} from the Segmentation Study

\section{Socio-demographics:}

... occurs in all age groups;

... is married as a rule, tends to have children under 15 years of age;

... has a medium/high income;

... has a medium/high level of education.

\section{Socio-cultural aspects:}

... is a family-oriented person who is pragmatic and has both feet on the ground; is balanced, sensible and looks for harmony;

... values inner qualities, simplicity and naturalness, according to the motto „It is quality not quantity that counts.“

... values quality of life, which means to them: family and friends, culture, comfort and quiet. It also means enjoying a life in moderation;

... is open-minded, tolerant, and interested in foreign cultures;

... is responsible and has a critical look at the current and social events;

... is an active person and does sports (walking, swimming, biking); enjoys nature and travelling;

... purchases products and brands that correspond to his or her way of life.

\section{Demands on products and brands:}

... domestic appliances have to be above all of top quality;

...values mature and usage-oriented technology;

...the appliances have to be easy to use for the whole family and robust;

...design should be harmonious, materials and colors should underline the quality of the appliance;

...is brand-oriented.

10 Source: BSH Internal materials, Segmentation study. 
Taking a closer look at the characteristics of the sociables, we can identify values that can combine very well with the core Bosch values of top quality, mature and usage-oriented quality. Sociables are brand-oriented, meaning that they prefer branded products, which is another important aspect.

The description of sociable that is available and has been made in previous text is based on the social demographics but more importantly on attitudes and usage good enough for development of strategic positioning. But for further implementation of the positioning at the operational level, it would be recommendable to go deeper and closer into these analyses to personalize them and, if possible, to create a specific profile of the target consumer. A few examples of what the profile might look like follow.

- Active and busy woman and/or mother that wants the best care for her family in her limited time;

- Whole family that expects convenience and a wide range of duties when handling a home appliance;

- Mother whose priority is the superior care of the child and family.

Such personalized profiles play the most important role in the development of a communication strategy, but seeing a specific personality behind the target group also helps when the other elements of the marketing strategy are developed.

To find such a personality or a profile of the target consumer that best represents the group, it is necessary to conduct specific market research to identify and/or test the individual profiles within the target group. As this is currently not available to and not planned by Bosch, the profile has not been specifically set. Based on the in-house experience and general definition of the target group, the major focus shall be on women, who are the majority users. Other members of the family are also considered important decision-makers and users. For the purpose of implementation, different deeper insights may be useful for various tools of making the marketing mix. While the product management will focus more on usage-oriented product features, for communication it is important to identify a clear profile of the target audience and to address it in an appropriate tone and manner.

Sociables were identified as a primary target group. But if we look back at Table 3 , we can identify secondary target groups in the individual countries, which come from the national segments oriented either on usage or on usage and the product. These segments may be considered as secondary targets as their characteristics and especially benefits expected are relatively close to those of the sociables and they may even be addressed with the same message targeted at the sociables, although not as directly. Table 6 shows potential primary and secondary target groups for the major European markets and their market sizes as a percentage of households in each country. 
Table 6

Market size of Bosch primary and secondary target groups on major European markets, in percentage of households

\begin{tabular}{|l|c|c|c|}
\hline & Primary target group & $\begin{array}{c}\text { Secondary target } \\
\text { group }\end{array}$ & $\begin{array}{c}\text { Total percent share } \\
\text { of all target groups }\end{array}$ \\
\hline Germany & Sociables & $\begin{array}{c}\text { Home Enthusiast, } \\
\text { Time Saver }\end{array}$ & \\
\hline $\begin{array}{l}\text { Percent share of TG in } \\
\text { population }\end{array}$ & $10.0 \%$ & $19.0 \%+10.0 \%$ & $39.0 \%$ \\
\hline UK & Sociables & $\begin{array}{c}\text { Shrewd Enthusiast, } \\
\text { Time Saver }\end{array}$ & \\
\hline $\begin{array}{l}\text { Percent share of TG in } \\
\text { population }\end{array}$ & $6.5 \%$ & $32.0 \%+5.0 \%$ & $435 \%$ \\
\hline France & Sociables & Simplicity Seeker & \\
\hline $\begin{array}{l}\text { Percent share of TG in } \\
\text { population }\end{array}$ & $17.0 \%$ & $24.0 \%$ & $41.0 \%$ \\
\hline Italy & Sociables & - & $35.0 \%$ \\
\hline $\begin{array}{l}\text { Percent share of TG in } \\
\text { population }\end{array}$ & $35.0 \%$ & $0.0 \%$ & $22.0 \%$ \\
\hline Spain & Sociables & Time Saver & \\
\hline $\begin{array}{l}\text { Percent share of TG in } \\
\text { population }\end{array}$ & $14.0 \%$ & $8.0 \%$ & \\
\hline
\end{tabular}

Source: BSH Internal materials, Segmentation study.

Table 6 also shows that the percentage proportion of the populations that represents these target groups is large enough in these countries and it will be effective to address them with a special message appealing to them.

The data summary shows that sociables are the ideal target group among those identified in the segmentation study. This target group corresponds well with the Bosch core values and desirable brand image (identity), is present on all Western European markets and is large enough to be worth the investment.

Sociables have been identified as a primary target group, as their profile best matches the core values of the Bosch brand in the home appliances sector as well as the core umbrella brand values.

\section{Summary}

The development of a positioning strategy relies on a thorough understanding of the company's consumers, competitors and business strategies. To be effective, brand positioning needs to resonate with the customer, differentiate the brand from competitors, and represent what the organization can and will do over time. Customers ultimately drive brand value and a brand strategy and positioning needs to be based on a powerful and precise segmentation strategy as well as in-depth knowledge of customers' needs and motivations. 
This article attempted to stress the most important theoretical bases of consumer analysis with the aim of identification of the target consumer through segmentation and targeting, and to demonstrate its application on a real case example. The process of identification of the target consumer has several steps and needs to reflect other positioning elements. All these aspects were demonstrated on the case example of Bosch home appliances.

Segmentation is a process of splitting all potential consumers into smaller groups - target groups according to different criteria depending on the aim of the segmentation. For the purpose of positioning it is necessary to use a complex set of criteria, which will identify consumers with similar attitudes and needs in relation to a given product group and brand (psychographic and behavioral patterns) and at the same time allow to identify these consumers (geo-demographic). In a specialized study focused on market segmentation, Bosch identified 15 different target groups across Europe together with their relatively detailed attitudes toward home appliances and their descriptions (the "sociables" target group was shown in detail).

Bosch has identified 15 homogenous target groups based on the main criterion of product benefit (consumer values, preferences, values). Consumers in these groups were described in a way that they could be identified and potentially reached by means of a marketing action:

- The size of each segment was identified for each of these target groups in each country (given as percentage of households).

- Profitability was considered as one of the major targets in the development of an internationally valid marketing strategy. The common brand position, including target groups across Europe, was motivated by cost-cutting reasons among others (brand equity and brand image improvement).

- The market life cycle is continuously followed (although not mentioned in the article) by Bosch through continuous market size and market share observations. New product development is important in this context.

- Thorough market analyses were conducted as part of the positioning strategy development (competition is one of the four major positioning elements).

In addition to the above mentioned aspects, while selecting the most suitable target group, Bosch considered criteria important for positioning strategy development, especially the compatibility between the target group preferences and expectations (product benefit) and brand equity (Bosch brand image, brand heritage, brand values, etc.).

Based on all these aspects, Bosch decided to select one major primary target group, which is present on all Western European markets: the sociables. In many countries a secondary target group was also identified, which the positioning strategy will not target fully but will address these consumers' major interests. The selected target group is homogenous, has an appropriate size for Bosch, and is brand-relevant. Competitive analyses showed that no competitor has the same position on the market (as Bosch desired position). 
Bosch has decided on a modified version of a concentrated strategy as it targets one segment, while also considering several secondary target groups as potential consumers. In the process of target group selection, Bosch also had to consider the positioning of other brands produced and marketed by the same company, Bosch und Siemens Hausgeräte. From the point of view of the company, we can talk about a differentiated strategy as it services different market segments with different brands.

This example demonstrates that marketing practice is very closely connected to the theory. The major difference between theory and reality is the scale of research that ican be conducted. From the theoretical point of view, Bosch should have conducted the segmentation study in two steps. In the first step, it should have concentrated on questioning households about their general preferences concerning home appliances as it did. But there should theoretically follow a second step in the study, which should concentrate on the sociables, their values, preferences (identification of the ideal benefit) and their perception of the Bosch brand (ideally even major competitors' brands) in even greater depth.

However, such a study would be very costly, complicated and time consuming even for a brand like Bosch. This shows that compromises are inevitable in practice. There are very many different methods and procedures, studies and market research tricks that can be used when analyzing consumers. The problem is that nobody, even the strongest multinational corporations, are capable of using them all. There are many obstacles, of which limited funds are usually the biggest. Market research is very expensive and there always have to be a compromise in fund allocation. But on the other hand, the attitude in which research is considered too expensive because the market situation is relatively clear and the resources are badly needed for media campaigns or other communications, is a common mistake and must be avoided in strategic cases such as positioning formulation.

\section{References}

AAKER, D. A. 1996. Building Strong Brands. The Free Press, 1996.

AAKER, D. A.; JOACHIMSTHALER, E. 2000. Brand Leadership. The Free Press, 1996.

BELCH, G. E.; BELCH M. A. 1995. Advertising and Promotion: an intergarated marketing communications. Irwin/Mcgraw-Hill, 1995.

KELLER, L. K. 1998. Strategic Brand Management. Prentice hall, 1998.

KOTLER, P. 1997. Marketing management, analýza, plánování, realizace a kontrola. Praha : Victoria Publishing, 1997.

KREILKAMP, E.; NÖTHEL, T. 1996. Zielgruppenfragmentierung durch Szene-Positionierung, Positionierung, Kernentscheidung des Marketings. St. Gallen : THEXIS, 1996.

KROEBER-RIEL, W.; ESCH, F. R. 2000. Strategie und Technik der Werbung. Stuttgart; Berlin; Köln : Kohlhammer, 2000.

KUSS, A.; TOMCZAK T. 1998. Marketingplannung. Wiesbaden : Gabler, 1998.

MACHKOVÁ, H. 2006. Mezinárodní marketing. Praha : Grada Publishing, 2006.

MEFFERT, H. 1998. Marketing: Grundlagen marktorientierter Unternehmensführung. Wiesbaden : Gabler, 1998. 
de MOOJI, M. K. 1998. Global Marketing and Advertising. Understanding Cultural Paradoxes. Saga Publications, 1998.

TROUT, J, RIVKIN, S. 2000. Differentiate or Die: Survival in Our Era of Killer Competition. John Wiley and Sons, 2000

TROUT, J.; RIES, A. 2001. Positioning: The battle for your mind. McGraw-Hill, 2001.

RIES, A.; RIES, L.1998. 22 Immutable Laws of Branding. HarperBusiness, 1998

Literature and Internal source of BSH Bosch und Siemens Hausgeräte used in Bosch Case Study: GFK Panel Market Data Western Europe 2000.

GFK Panel Market Data Western Europe 2001.

Group Annual Report BSH 2000.

Group Annual Report BSH 2001.

Markenfundament, Corporate Design Manual, Bosch internal Source, 2001.

Brand Trek, Bosch, Die Marke Bosch aus der Sicht der Verbraucher in Frankreich, Italien, Spanien, USA, Brasilien, Japan. Stuttgart, 2001.

Research International, Market research studies prepared for BSH (Brand trek study), 2001.

Bosch-Markenidee, Internal source, 2001.

\title{
IDENTIFICATION OF A TARGET CONSUMER IN PROCESS OF POSITIONING STRATEGY DEVELOPMENT - THEORETICAL AND PRACTICAL ASPECTS
}

\begin{abstract}
Positioning is an important tool of marketing strategic planning and of a brand building process. Brand positioning development incorporates analyses and definition of four major elements - target consumer (target group), consumer benefit, brand image and competitive frame of reference. All elements of positioning are interconnected and all of them are influenced by selection of target consumer. The article is concentrated on major steps of identification of the target consumer as a part of brand positioning strategy development. It demonstrates application of the theoretical attitude of segmentation on practical example of Bosch home appliances brand. Summary contains comparison of theory and practical case of segmentation and targeting process as a part of brand positioning development.
\end{abstract}

Keywords: positioning, segmentation, target group

JEL Classification: M31 